\title{
Evaluation of the effects of fermentation of buffalo curd and acidity on survival kinetics of Listeria monocytogenes
}

\author{
VS Jayamanne $^{1}$ and U Samarajeewa ${ }^{2}$ \\ ${ }^{1}$ Dept of Food Science \& Technology, Faculty of Agriculture, University of Ruhuna, Kamburupitiya, Sri Lanka \\ ${ }^{2}$ Dept of Food Science \& Technology, Faculty of Agriculture, University of Peradeniya, Peradeniya, Sri Lanka
}

Accepted : $7^{\text {th }}$ September 2010

\begin{abstract}
Listeria monocytogenes, a food-borne pathogen often found in milk and milk products, causes listeriosis in pregnant women, newborns, elderly and immuno-suppressed people. There have been reports on survival of Listeria in various milk products in the world, but comparable studies on the survival of Listeria in buffalo curd have not been reported. Therefore, the present study investigated the effects of fermenting buffalo milk and acidity on survival kinetics of $L$. monocytogenes. L. monocytogenes FSTLC2 and lactic acid starter cultures were aseptically introduced to boiled and cooled buffalo milk (fat $6 \%$, protein $4 \%$ ) and the mix was allowed to ferment at ambient temperature $\left(26 \pm 2^{\circ} \mathrm{C}\right)$ for $18 \mathrm{~h}$. The Listeria count on Modified Oxford Agar (MOX; Oxoid Ltd.), lactic acid bacteria count on MRS Agar (Oxoid Ltd.), $\mathrm{pH}$ and titratable acidity were determined in the beginning and at $2 \mathrm{~h}$ intervals during fermentation. The effect of $\mathrm{pH} /$ acidity on Listeria was determined by introducing Listeria to buffalo milk with $\mathrm{pH}$ values (pH 4.0, 4.5, 5.0, 5.5) adjusted using $88 \%$ lactic acid (BDH Chemicals) and enumerating Listeria on MOX Agar at 12h intervals for 96h. It was observed in the present study that Listeria count decreased over time and after $\mathbf{1 6} \mathrm{h}$ of fermentation of buffalo milk at ambient temperature, Listeria cannot be detected on MOX Agar. The pH value decreased from 6.8 to 4.1 and titratable acidity (lactic acid $\%$ ) increased from $0 \%$ to $1.2 \%$ during fermentation. Fermentation appeared to be an effective preservation technique in eliminating Listeria in buffalo curd. The $\mathrm{pH}$ value of 5.5 appeared to be the critical pH for inactivation of Listeria as no growth of Listeria was observed below pH 5.5. The total inactivation of Listeria in buffalo milk appeared to be due to lowering of $\mathrm{pH}$ coupled with increasing titratable acidity as well as action of bacteriocins, especially Nisin, produced by lactic acid bacteria during fermentation. It is clear that fermentation is an effective tool in inactivating Listeria in buffalo milk.
\end{abstract}

Keywords: Listeria monocytogenes, Buffalo curd, Fermentation, Inactivation, Acidity

\section{INTRODUCTION}

Listeria monocytogenes, which is a Gram-positive, facultatively anaerobic, cold tolerant, salt tolerant, non-spore forming and non-acid fast rod often found in soil and water, and faeces of animals, is a relatively recent food-borne pathogen reported mostly from developed countries (Maijala et al. 2001; Karakolev 2009). L. monocytogenes is a food -borne pathogen of high concern to the food industry as its ubiquitous occurrence in the environment can lead to contamination of foods. The toxic substance produced during the exponential growth phase of L. monocytogenes is designated listeriolysin $\mathrm{O}$ (hemolysin), which causes hemolysis of blood agar in in-vitro studies. When L. monocytogenes is contracted through the oral route, it apparently colonizes the intestinal tract by mechanisms that are poorly understood. From the intestinal tract, the organism invades tissues including the placenta in pregnant women, and enters the blood stream, from which it reaches other susceptible body tissues. Listeriosis, the illness caused by this bacterium, affects mostly pregnant women, elderly, newborns, and the immuno-suppressed adults due to AIDS, alcoholism, diabetes, cancer, cardiovascular disease, kidney disease, renal transplant, and corticosteroid therapy (Rocourt et al. 2000). When susceptible adults contract the disease, meningitis and septicemia are the most commonly recognized symptoms. The non-pregnant healthy individuals who are not immuno-suppressed are fairly resistant to infection by L. monocytogenes. Infected pregnant women may experience only mild flu-like illness, and the illness can be transmitted from mother to the fetus through the placenta resulting in abortion, premature birth, stillbirth, or serious health problems for the newborn child. The mortality rate of the disease is approximately $25 \%$ (USDA 1999).

Milk and milk products have received much attention because they have been reported to harbor $L$. monocytogenes to a much higher extent compared to other foods. L. monocytogenes has been isolated from cow milk, goat milk, cheese, and pasteurized milk in Sri Lanka (Jyamanne and Samarajeewa

\footnotetext{
*Corresponding author : vsjayamanne@fst.ruh.ac.lk

Paper presented at the $2^{\text {nd }}$ National Symposium, Faculty of Agriculture, University of Ruhuna
} 
2001). There have been reports of Listeria outbreaks associated with dairy products (Farber and Peterkin 1991). Cow milk has been implicated in food-borne fatal listeriosis. The ability of L. monocytogenes strains to proliferate in raw milk even under refrigerated condition is well documented.

Though milk and milk products were reported to transmit food-borne listeriosis, only two studies have been reported in Sri Lanka to ascertain the safety of the dairy products. In a survey on Listeria in foods, it was demonstrated that the percentage of L. monocytogenes positive samples was highest among vegetables (49\%), second in chicken (34\%), and lowest in dairy products $(26 \%)$ (Gunasena et al. 1995). They further observed that 5 pasteurized milk (31\%), 3 raw milk (25\%) and 4 ice cream (33\%) samples contained L. monocytogenes. In a similar study, of the samples tested (265), 39 samples $(15 \%)$ contained virulent $L$. monocytogenes. Cow milk (29\%), goat milk (27\%), pasteurized milk $(17 \%)$, and cheese $(33 \%)$ samples contained virulent strains of L. monocytogenes (Jayamanne \& Samarajeewa 2001). They further observed the complete absence of Listeria in buffalo curd. However, no studies on the effect of fermenting buffalo milk on survival of Listeria have been carried out. Therefore, the present study investigated the survival kinetics of Listeria in fermenting buffalo milk and at different $\mathrm{pH}$ values at ambient temperature $\left(26 \pm 2^{\circ} \mathrm{C}\right)$.

\section{MATERIALS AND METHODS}

Two major experiments were carried out to determine the effect of fermentation of buffalo curd and added acidity on the survival kinetics of L. monocytogenes.

\section{Effect of fermentation of buffalo curd on the survival kinetics of $L$. monocytogenes}

Buffalo milk (fat $\sim 6 \%$, protein $\sim 4 \%$ ) was aseptically collected and was boiled for 5 min to destroy all the organisms. Boiled buffalo milk $(250 \mathrm{ml})$ was poured into sterile clay pots. Boiled buffalo milk was first tested for Listeria using the FDA Listeria Enrichment Broth (LEB; Oxoid Ltd., Basingstoke, UK) and Modified Oxford Agar medium (MOX; Oxoid Ltd.) in order to ensure that milk was not contaminated with Listeria.

In the enumeration process of the organism, Listeria in milk was first enriched in FDA Listeria Enrichment Broth. Samples $(25 \mathrm{ml})$ were blended with LEB $(225 \mathrm{ml})$ at $12,000 \mathrm{rpm}$ for $2 \mathrm{~min}$ in a Waring blender. The resulting solution was incubated at $35^{\circ} \mathrm{C}$ for $48 \mathrm{~h}$ for selective enrichment and the selective isolation of Listeria was done in MOX. En- riched samples were next streaked onto MOX Agar plates and incubated at $35^{\circ} \mathrm{C}$ and examined for colonies with black halos after 24,48 and $72 \mathrm{~h}$. Single colonies growing on the MOX medium were isolated and transferred to MOX agar slants in McCartney bottles and incubated at $35^{\circ} \mathrm{C}$ until there was sufficient growth. The MOX agar slants were stored in the refrigerator at $3 \pm 2^{\circ} \mathrm{C}$ pending confirmatory morphological and biochemical tests. MOX agar slants were sub-cultured at 3-month intervals to ensure the viability of organisms. The tests [microscopy on wet mount, Gram staining, catalase test, methyl red (MR) test, VogusProskauer (VP) test, $\mathrm{H}_{2} \mathrm{~S}$ production, color changes in Triple Sugar Iron Agar, color changes in Urea Agar, hydrolysis of aesculin and CAMP test] were carried out to confirm the presence of Listeria in the food samples.

Three Sub experiments were carried out to determine the effect of fermentation of buffalo curd on survival kinetics of L. monocytogenes.

An inoculum of starter culture (2\%) from a day old buffalo curd pot was introduced to boiled buffalo milk $(250 \mathrm{ml})$ and allowed to ferment at ambient temperature $\left(26 \pm 2{ }^{\circ} \mathrm{C}\right)$. The total lactic acid bacteria on MRS Agar (Oxoid Ltd.), $\mathrm{pH}$ value, and titratable acidity in the beginning and at $2 \mathrm{~h}$ intervals, were recorded during fermentation. The $\mathrm{pH}$ values were determined using a portable $\mathrm{pH}$ meter (Model HI8424; Hanna Instruments, Milan, Italy). The pH meter was calibrated using standard $\mathrm{pH}$ buffers 4.0 and 7.0 before use. The titratable acidity was determined by titrating $10 \mathrm{~g}$ of fermented milk (mixed with $10 \mathrm{ml}$ of hot water) against $0.1 \mathrm{M} \mathrm{NaOH}$ to a phenolphthalein $(0.5 \%)$ end point and expressed as percent lactic acid according to the Standard formulae (AOAC 1985).

L. monocytogenes FTSLC2 (University of Peradeniya Culture Collection), previously isolated from raw cow milk, from the culture collection was enriched in LEB at $35^{\circ} \mathrm{C}$ for $48 \mathrm{~h}$, transferred to Tryptose Broth $(10 \mathrm{ml})$ and incubated for $48 \mathrm{~h}$ at $35^{\circ} \mathrm{C}$. A loopful of enriched Listeria culture was aseptically transferred to McCartney bottles containing $20 \mathrm{ml}$ of Tryptose Broth (Oxoid Ltd.), incubated for another $24 \mathrm{~h}$ at $35^{\circ} \mathrm{C}$. After $24 \mathrm{~h}$ of incubation in Tryptose Broth, the Listeria cells at the late stationary phase were harvested by centrifugation at $6,000 \times \mathrm{g}$ for $20 \mathrm{~min}$. Listeria was introduced to boiled and cooled buffalo milk $(250 \mathrm{ml})$ in clay pots to have an initial Listeria population of approximately $10^{5} \mathrm{cfu} / \mathrm{ml}$, and it was obtained by the surface plate count method on MOX Agar. The Listeria count on MOX Agar and $\mathrm{pH}$ values were recorded in the beginning and at two-hour intervals of 
the fermenting milk solution at ambient temperature $\left(26 \pm 2^{\circ} \mathrm{C}\right)$.

The inoculum (2\%) of previously fermented curd was aseptically introduced to boiled buffalo milk. L. monocytogenes was also introduced to boiled buffalo milk $(250 \mathrm{ml})$ at the same time to have an initial Listeria population of $10^{5} \mathrm{cfu} / \mathrm{ml}$. The Listeria count on MOX Agar, lactic acid bacteria count on MRS Agar, $\mathrm{pH}$, titratable acidity of the fermenting milk solution at ambient temperature $\left(26 \pm 2^{\circ} \mathrm{C}\right)$ were taken simultaneously in the beginning, and at two-hour intervals during fermentation. Logarithmic survival number of Listeria, total lactic acid bacterial count, and $\mathrm{pH}$ values ( $\mathrm{Y}$ axis) were plotted against time ( $\mathrm{X}$ axis).

It can be hypothesized that the $\mathrm{pH} /$ acidity plays a major role in inactivating Listeria in buffalo milk and lactic acid is the acid that is formed during fermentation. Therefore, a separate experiment was carried out to determine the effect of different concentrations of lactic acid on the survival of Listeria in buffalo milk.

\section{Determination of the effect of $\mathrm{pH}$ on the survival of L. monocytogenes}

L. monocytogenes FSTLC2 (University of Peradeniya Culture Collection), previously isolated from raw cow milk, from the stored culture collection was enriched in LEB at $35^{\circ} \mathrm{C}$ for $48 \mathrm{~h}$. A loopful of the enriched Listeria culture was aseptically transferred to Tryptose Broth and incubated at $35^{\circ} \mathrm{C}$ for further $48 \mathrm{~h}$. After $24 \mathrm{~h}$ of incubation in Tryptose Broth, the Listeria cells at the late stationary phase were harvested by centrifugation at $6000 \times \mathrm{g}$ for 20 min. Buffalo milk was boiled for 5 min to destroy microorganisms. Boiled buffalo milk $(250 \mathrm{ml}$ each) was aseptically transferred to four Erlenmeyer flasks. Acidity of boiled milk in Erlenmeyer flasks was adjusted using 80\% lactic acid (BDH Chemi-

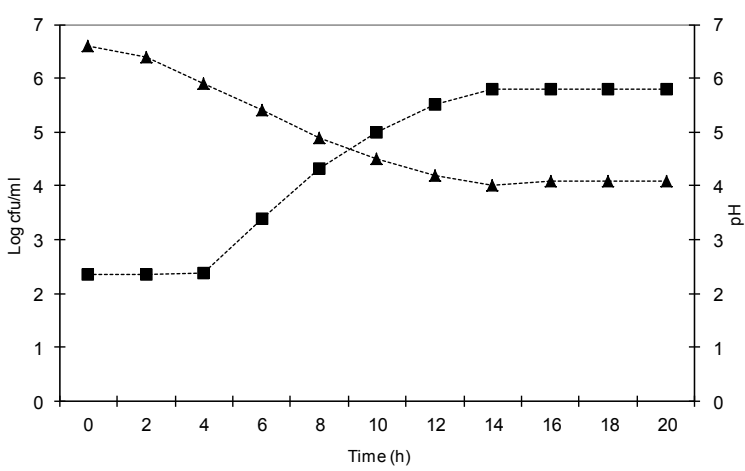

Figure 1: Total lactic acid bacteria count on MRS Agar (घ) and changes in $\mathrm{pH}(\Delta)$ in buffalo curd during fermentation at ambient temperature $\left(26 \pm 2{ }^{\circ} \mathrm{C}\right)$ cals, UK) to obtain different $\mathrm{pH}$ values such as 5.5, 5.0, 4.5 and 4.0. Listeria was introduced to boiled and cooled buffalo milk $(250 \mathrm{ml})$ to have an initial Listeria population of approximately $10^{5} \mathrm{cfu} / \mathrm{ml}$. A surface count of Listeria on MOX Agar was taken in duplicate at $12 \mathrm{~h}$ intervals for a period of $96 \mathrm{~h}$ at ambient temperature $\left(26 \pm 2^{\circ} \mathrm{C}\right)$. A graph of the $\log$ survival number of Listeria (Y axis) against time (X axis) was plotted.

\section{RESULTS AND DISCUSSION}

Fermentation appeared to be an effective tool in eliminating Listeria from buffalo milk. After 16h of fermentation of buffalo milk at ambient temperature Listeria was not detected on MOX Agar.

\section{Effect of fermentation of buffalo milk on growth dynamics of $L$. monocytogenes}

It was observed that when the inoculum from previously fermenting buffalo curd was introduced at $2 \%$ concentration to boiled buffalo milk and incubated at room temperature $\left(26 \pm 2^{\circ} \mathrm{C}\right)$, the lactic bacteria started to proliferate and reached its maximum (approximately $10^{6} \mathrm{cfu} / \mathrm{ml}$ ) after $14 \mathrm{~h}$ of fermentation (Figure. 1). The $\mathrm{pH}$ value decreased from 6.8 to 4.1 during $14 \mathrm{~h}$ fermentation. It can be safely assumed that almost all the bacteria in the inoculum of previously fermented curd are lactic acid bacteria, because during fermentation the growth of other organisms is inhibited by decreasing $\mathrm{pH}$, increasing titratable acidity and bacteriocins. The total plate count on MRS Agar in the fermenting buffalo curd solution could almost represent the lactic acid bacteria.

When L. monocytogenes FSTLC2 was introduced at a population of $10^{5} \mathrm{cfu} / \mathrm{ml}$ to boiled buffalo milk after cooling to room temperature, Listeria count decreased with time, and after $16 \mathrm{~h}$ of fermentation

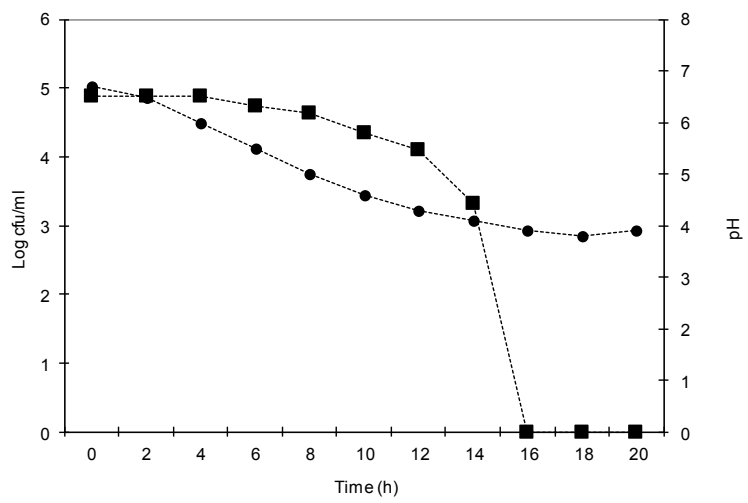

Figure 2: Survival of L. monocytogenes FSTLC2 (ø) and changes in $\mathrm{pH}(\bullet)$ during fermentation of buffalo milk at ambient temperature $\left(26 \pm 2{ }^{\circ} \mathrm{C}\right)$ 
with an inoculum of fermenting curd at ambient temperature, Listeria cannot be detected on MOX Agar (Figure. 2). In the fermentation process, the $\mathrm{pH}$ decreased from 6.8 to 4.1 . It is evident that at pH 5.5, the Listeria count begins to drop sharply (Fig. 2). The $\mathrm{pH}$ value 5.5 appeared to be the critical point for inactivation of Listeria in fermenting buffalo milk. When both the total bacterial and Listeria counts were taken simultaneously in fermenting buffalo curd, an inverse relationship between the total bacterial count and L. monocytogenes was apparent (Figure. 3). It was observed that when the total bacterial count increases, the Listeria count decreases, and the $\mathrm{pH}$ decreases from 6.8 to 4.1 (Figure. 3). It appears that fermentation eliminates Listeria from buffalo curd. This could be mainly due to lowering of $\mathrm{pH}$ and increasing acidity. Although the $\mathrm{pH}$ decrease in later stages of fermentation was small compared to the rapid drop during initial fermentation, the titratable acidity increased steadily from $0 \%$ to $1.2 \%$. The combination of low $\mathrm{pH}$ and increasing titratable acidity would result in increasing levels of undissociated acid, which is more harmful to microorganisms and is clearly a factor in the rapidly decreasing listerial population towards the end of fermentation (Figure. 3) (Adams $\&$ Moss 2000). Additionally, production of antilisterial substances by lactic acid bacteria, and the action of natural lactoperoxidase system present in milk may be playing a contributory role. Of the three factors, the lowering of $\mathrm{pH}$ coupled with increasing acidity could be the most important factor in inhibiting the Listeria in milk.

It was reported that inhibition of L. monocytogenes in fermented milk products is associated with the decrease in $\mathrm{pH}(<4.0)$ (Zuniga et al. 1995). Other micro-flora of fermented milk products is also reported to increase the death rate of L. monocytogenes during storage at $20^{\circ} \mathrm{C}$ (Stanczak et al. 1997).

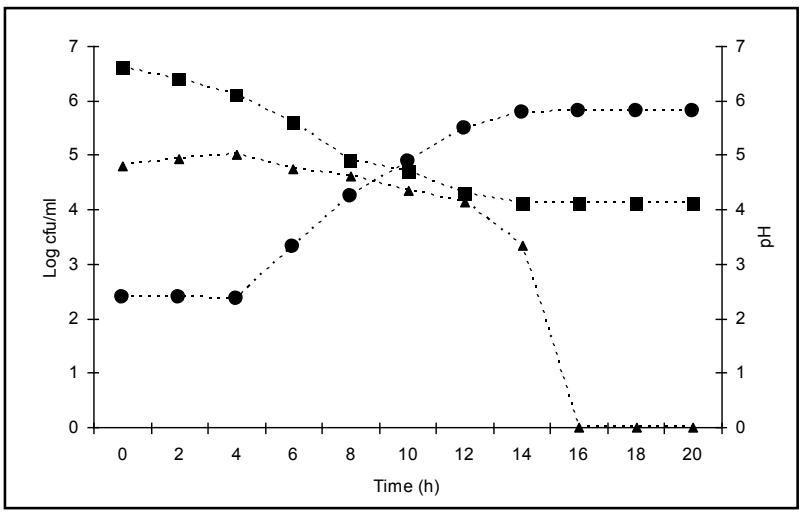

Figure 3: Population level of $L$. monocytogenes FSTLC2 on MOX ( $\triangle)$, total lactic acid bacteria count on MRS Agar $(\bullet)$ and changes in pH (ø) during fermentation of buffalo milk at ambient temperature $\left(26 \pm 2^{\circ} \mathrm{C}\right)$
Lactic acid bacteria and their metabolic products have a direct impact on L. monocytogenes. The lactic acid bacteria compete with other organisms for nutrients and they produce antibacterial compounds including weak acids, hydrogen peroxide, diacetyl and bacteriocins (for example nisin and pediocin). A large number of bacteriocins from lactic acid bacteria are active against $L$. monocytogenes. It was reported that these bacteriocins usually destabilize the cytoplasmic membrane of sensitive cells, increase membrane permeability, and dissipate the proton motive force by forming water-filled transmembrane pores or channels (Jack et al. 1995). Nisin, a bacteriocin produced by certain strains of Lactococcus species has proven to be useful in suppressing the growth of $L$. monocytogenes (Mohamed et al. 1980). Further, L. lactis is a bacterial species that is normally present in the inoculum used to produce buffalo curd.

The observations in the present study suggest that fermentation is a useful food preservation technique for elimination of L. monocytogenes. Fermentation appears to be able to eliminate an initial Listeria population of approximately $10^{5} \mathrm{cfu} / \mathrm{ml}$ in buffalo curd. It is also notable that none of the buffalo curd or yoghurt sample tested in a previous study (Jayamanne \& Samarajeewa 2001), contained Listeria indicating the effectiveness of fermentation in inhibiting Listeria growth. The consumption of fermented buffalo curd is therefore safe with regard to human listeriosis.

\section{Effect of pH on survival of L. monocytogenes}

It was observed that an initial L. monocytogenes FSTLC2 population of $10^{5} \mathrm{cfu} / \mathrm{ml}$ survived only 48 $\mathrm{h}$ at $\mathrm{pH} 4.0$, when Listeria was introduced to boiled buffalo milk after adjusting $\mathrm{pH}$ using lactic acid (Figure. 4). Furthermore, maintenance of a population level of $L$. monocytogenes in milk at $\mathrm{pH} 5.5$

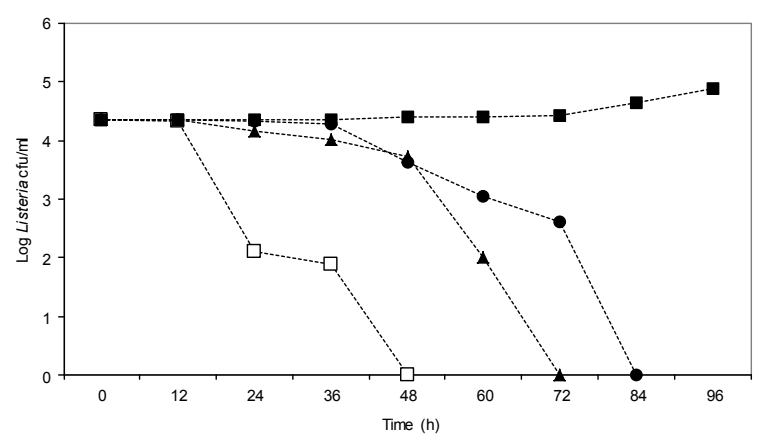

Figure 4: Survival of L. monocytogenes FSTLC2 in bovine milk at $\mathrm{pH}$ values of $4.0(\square), 4.5(\Delta), 5.0(\bullet)$ and 5.5 (घ) at ambient temperature $\left(26 \pm 2^{\circ} \mathrm{C}\right)$ 
was observed (Figure. 4). The minimum $\mathrm{pH}$ value for survival of Listeria appears to be 5.5, and $\mathrm{pH}$ values below 5.5, inhibit the growth of Listeria (Figure. 4). Lactic acid, which is reported to have deleterious effects on Listeria, was used to acidify the medium. It is reported that at the same $\mathrm{pH}$, the relative anti-microbial activity caused by added acids follows the order of acetic acid $>$ lactic acid $>$ citric acid $>$ malic acid $>\mathrm{HCl}$ (Sorrells et al. 1989). In comparable studies on effect of $\mathrm{pH}$, it was reported that L. monocytogenes can only grow at $\mathrm{pH}$ values from 5.6 to 9.6 , with optimal growth occurring at neutral to slightly alkaline $\mathrm{pH}$ values (Petran and Zotolla 1989). It was also reported that $L$. monocytogenes failed to grow in Dextrose (glucose) Broth at $\mathrm{pH}$ less than 5.6 after 2-3 days of incubation at $37^{\circ} \mathrm{C}$, and in addition, routine subculturing from the medium was nolonger successful (Seeliger 1961).

All evidence, from the present study and reported work suggest the possibility of using $\mathrm{pH}$ as a mean to control Listeria activity in milk. It appears that the observed inactivation of Listeria in buffalo curd could be due to the $\mathrm{pH} /$ acidity and bacteriocins produced by lactic acid bacteria, and the natural lactoperoxidase system, because a $\mathrm{pH}$ of 4.0 alone took $48 \mathrm{~h}$ to inactivate Listeria (Figure. 4)

The apparent inability of $L$. monocytogenes to survive at $\mathrm{pH}$ values below 5.5 , both observed in the present study and reported by other scientists, could be a useful tool in food product formulations. It appears that Listeria can withstand low and high temperatures, tolerate salt, grow anaerobically, and adapt to various environmental stresses. But, in general Listeria does not appear to be able to withstand low $\mathrm{pH}$ or acidity. This phenomenon can be made use of in food product developments where all other growth parameters are less effective. It is also evident that lactic acid is suited to acidify food formulations in order to arrest Listeria growth.

\section{CONCLUSIONS}

Fermentation appeared to be an effective preservation technique to eliminate Listeria in buffalo curd. The $\mathrm{pH}$ value of 5.5 appeared to be the critical $\mathrm{pH}$ for inactivation of Listeria as no growth of Listeria was observed below $\mathrm{pH}$ 5.5. The total inactivation of Listeria in buffalo milk may be due to lowering of $\mathrm{pH}$ coupled with increased acidity as well as action of bacteriocins produced by lactic acid bacteria during fermentation. Lactococcus lactis in the buffalo curd culture appeared to produce nisin that has an inhibitory effect on Listeria. Further, lowering of $\mathrm{pH}$ in food can be an effective method to arrest listerial growth in milk and milk products.

\section{Acknowledgements}

The authors gratefully acknowledge the assistance given by Mr PK Liyanage (Dept of Food Science \& Technology, University of Peradeniya) and Mrs. S Abeysekare (Dept of Food Science \& Technology, University of Ruhuna) in preparing microbiological media and taking readings.

\section{REFERENCES}

Adams MR and Moss MO 2000 Fermented and Microbial Foods. In: Food Microbiology. $2^{\text {nd }}$ edn. The Royal Society of Chemistry, Cambridge, UK. pp. 311 -368 .

AOAC 1985 Official Methods of Analysis. 14 ${ }^{\text {th }}$ edn. Association of Official Analytical Chemists, Washington DC, USA.

Farber JM and Peterkin PI 1991 Listeria monocytogenes, a food-borne pathogen. Microbiol. Rev. 55: 476-511.

Jack RW, Tagg JR and Ray B 1995 Bacteriocins of Gram-positive bacteria. Microbiol. Rev. 59: 171-200.

Jayamanne VS and Samarajeewa U 2001 Incidence and detection of Listeria monocytogenes in milk and milk products of Sri Lanka. Trop. Agric. Research. 13: 4250.

Karakolev R 2009 Incidence of Listeria monocytogenes in beef, pork, raw-dried and raw-smoked sausages in Bulgaria. Food Control. 20(10): 953-955.

Mohamed GEE, Seaman A and Woodbine A 1980 Food antibiotic nisin: Comparative effects on Ersipelothrix and Listeria. In: M. Woodbine (ed). Antimicrobials and Agriculture, London: Butterworths, pp. 435-442.

Maijala R, Lyytikainen O, Johansson T, Autio T, Aalto T, Haavisto L and Honkanen-Buzalski T 2001 Exposure of Listeria monocytogenes within an epidemiccaused by butter in Finland. Int. J. Food Microbiol.70: 97-109.

Petran RL and Zottola EA 1989 A study of factors affecting growth and recovery of Listeria monocytogenes Scott A. J. Food Sci. 54: 458-460.

Rocourt J, Jacquet C and Reilly A 2000 Epidemeology of human listeriosis and seafoods. Int. J. Food Microbiol. 67: 197-209.

Seeliger HPR 1961 Listeriosis. New York: Hafner.

Sorrells KM, Enigl DC and Hatfield JR 1989 Effect of $\mathrm{pH}$, acidulant, time, and temperature on the growth and survival of Listeria monocytogenes. J. Food Prot. 52: 571-573.

Stanczak BJ, Szczawinski J and Peconek J 1997 Survival of Listeria monocytogenes in fermented milk products. Medycyna-Weterynaryjna. 5(10): 592-595.

United States Department of Agriculture 1999 Consumer Information from USDA. Food Safety Education Office, Food Safety and inspection service, USDA, Washington D.C. 20250-3700, USA.

Zuniga EA, Lopez MA and Mota DLGL 1995 Behaviour of Listeria monocytogenes in milk fermented with a yogurt starter culture. Revista-Latinoamericana-deMicrobiologia. 37(3): 257-265. 